\title{
Economia política \\ e a história das doutrinas econômicas
}

\section{DIVA BENEVIDES PINHO}

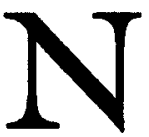

esta síntese queremos apenas pontuar a trajetória do ensino e da pesquisa de Economia que da FFCL-USP integrou-se na FEA-USP: a cadeira de Economia Politica e Historia das Doutrinas Economicas do curso de Ciências Sociais da FFCL-USP. Marcada por uma concepçáo de Economia predominantemente especulativa, pura, desinteressada, em busca da interpretafáo do mundo econômico a partir de debates fundamentalmente doutrinários, no fim de 1969, foi transferida para o recém-criado Departamento de Economia da FEAUSP, uma Faculdade profissionalizante, voltada para a ação e especializada nas áreas de Ciências Econômicas, Contábeis e Atuariais (com quinze docentes incumbidos de ministrar quatro anos do curso de graduaçáo e três cursos de especializaçáo, nos períodos diurno e noturno).

Essa trajetória reflete, em grande parte, as transformaçóes econômicas e sociais do Brasil e, em especial, do estado de São Paulo, desde a década de 30, quando chegaram as missóes estrangeiras (italiana, alemá e francesa) para as áreas de ciências exatas e de humanidades da Universidade de São Paulo, até os anos 60. Nesse período, o Brasil passou de uma economia essencialmente primário-exportadora a um país de economia complexa, voltada para dentro, diante do declínio temporário de suas exportaçóes, da necessidade de suprir sua própria demanda interna e de comprimir suas importaçóes não-essenciais, forçado, sobretudo, pela retraçáo do mercado internacional, como decorrência da crise mundial de 1929/30 e da Segunda Grande Guerra.

No estado de São Paulo, as mudanças e a expansão da estrutura produtiva efetuaram-se mais intensamente porque a economia cafeeira criara relativa abundância de economias externas e os investimentos do crescente empresariado privado apresentaram significativa mutiplicação da renda e do emprego. Então, um complexo parque industrial juntouse à tradicional economia agrícola exportadora e ao setor bancário e financeiro, provocando significativo crescimento do setor terciário. 
Em sua provinciana capital dos anos $\mathbf{3 0}$, uma reduzida elite intelectual, que falava francês correntemente e deleitava-se com especulaçóes teóricas e doutrinárias desinteressadas, contribuiu para estimular, no curso de Ciências Sociais, um programa de Economia com embasamento teórico (noçóes fundamentais de economia, mercado, moeda e bancos, comércio internacional, desenvolvimento econômico) e amplas análises doutrinárias (do liberalismo econômico ao socialismo utópico, marxista e pós-marxista, passando por várias doutrinas intermedidirias), mas sempre com a preocupaçăo de considerar as peculiaridades do ambiente sócio-econômico, cultural e político do Brasil.

E assim, a cadeira de Economia Política e História das Doutrinas Econômicas da FFCL-USP passou a representar suporte dos estudos de Sociologia, Antropologia e Política, concentrando-se na análise qualitativa da atividade econômica, dentro de um enfoque doutrinário e humanista. Seu corpo docente foi incialmente recrutado em faculdades de Direito da França, integrando a Misstio Francesa: François Perroux (1936), René Courtin (1937), Pierre Fromont (1938) e Paul Hugon (de 1939 a 1971).

Na metade dos anos 40, o professor Hugon participou do grupo de constituiçăo de um Instituto dedicado essencialmente ao ensino e à pesquisa de Ciências Econômicas - já previsto nos Estatutos da USP, em 1934. Em 1946, foi contratado para cadeira semelhante da FCEA - Economia Política e História das Doutrinas Econômicas, levando como seu primeiro assistente José Francisco de Camargo, também seu assistente na FFCL-USP - depois catedrático da FCEA. Seus outros assistentes, Dorival Teixeira Vieira e Lenita Corrêa Camargo, também integraram o corpo docente da FCEA, tornando-se, mais tarde, catedráticos; outros discípulos passaram igualmente a atuar $\mathrm{em}$ várias cadeiras da nova Faculdade.

Portanto, diferentemente da FFCL, que recorreu a missóes estrangeiras, a FCEA recrutou a maioria de seu corpo docente na própria USP, principalmente na FFCL, Direito e Poli. Devido à forte valorização do ensino especulativo e desinteressado, os docentes-pioneiros da FCEA enfrentaram, a princípio, preconceito contra o ensino de caráter profissionalizante e técnico, que impunha treinamento dos próprios docentes junto ao mercado e redirecionamento da formação teórica decorrente do contato com a realidade.

Concomitantemente, por volta de 1955 , começou a se difundir no Brasil uma espécie de euforia nacionalista-desenvolvimentista, acompanhada de crescente aparelhamento do Estado como planejador. E, 
nessa tarefa de se equipar para promover o planejamento e a execução de planos setoriais, regionais ou globais de desenvolvimento, pressentia-se a tendência de aumento da demanda de economistas por parte dos governos da Federaçăo, dos estados e dos municípios.

Iniciou-se, também, uma ebuliçăo metodológica ligada a uma concepçáo de economia que não mais se contentava em interpretar o mundo econômico, mas que desejava transformá-lo e, para tanto, deveria dispor de complexo intrumental analítico, especialmente matemático e estatístico. Então, a FCEA passou a se reestruturar em torno da Teoria Econômica como área fundamental dos cursos de economia, predominando a concepçáo de estudos teóricos voltados para a açáo, ou seja, para explicar, compreender e prever a atividade econômica e, principalmente, para agir no mundo real.

Com a Reforma Universitária de 1969, o ensino de economia em Ciências Sociais foi reduzido a apenas dois semestres de noçóes introdutórias, ministrados por professor designado pelo Departamento de Economia da FEA, enquanto esta recebeu todos os integrantes da cadeira de Economia Política e História das Doutrinas Econômicas. E assim o professor Paul Hugon, que atuara na constituiçáo da entáo FCEA e nos dez primeiros anos de seu funcionamento, retornou depois de um hiato de permanência apenas em Ciências Sociais. Juntamente com ele vieram seus assistentes, cinco dos quais tornaram-se professores titulares. Outros, passaram a atuar também no mercado de trabalho ou em assessorias governamentais.

Aliás, desde os anos 60 até recentemente, a FEA tornou-se centro de demanda de economistas/assessores governámentais; e, para a área econômica governamental, foram recrutados vários secretários estaduais de São Paulo e ministros do governo federal.

A FEA firmou-se, a partir dos anos 70, como centro de excelencia, tanto na docência quanto na área de pesquisas e estudos de alto nível, contando inclusive com um Instituto de Pesquisas Econômicas (IPE) e uma Fundação Instituto de Pesquisas Econômicas (Fipe). Vários professores foram doutorar-se nos EUA, acentuando-se a fase de crescente influência de economistas norte-americanos.

Mas a linha humanista que vem desde seus docentes-pioneiros e dos membros da cadeira de Economia Política e História das Doutrinas Econômicas, do curso de Ciências Sociais da então FFCL-USP, transparece ainda na estrutura curricular, que procura dar aos futuros economistas uma formação na qual a atividade econômica não é concebida apenas como relaçóes entre indivíduos considerados como seres abstra- 
tos, mas sim como seres humanos dentro de uma realidade dinâmica $\mathrm{e}$ complexa.

Dipa Benerides Pinho foi professora da cadeira de Economia Política e Historia das Doutrinas Económicas da Faculdade de Filosofia, Letras e Ciéncias Humanas da USP. Desde 1970 é professora do Departamento de Economia da Faculdade de Economia e Administraçäo da USP. 